\title{
ANALISIS POTENSI CYCLIC MOBILITY PADA TANAH KOHESIF
}

\author{
Nicky Fernando ${ }^{1}$ dan Aniek Prihatiningsih ${ }^{2}$ \\ ${ }^{1}$ Program Studi Sarjana Teknik Sipil, Universitas Tarumanagara, Jl. Letjen S. Parman No.1 Jakarta \\ Email: nickyfernando41@gmail.com \\ ${ }^{2}$ Program Studi Sarjana Teknik Sipil, Universitas Tarumanagara, Jl. Letjen S. Parman No.1 Jakarta \\ Email: aniekp@ft.untar.ac.id
}

\begin{abstract}
ABSTRAK
Likuifaksi merupakan fenomena dimana kekuatan tahanan tanah berkurang karena meningkatnya tegangan air pori saat gempa bumi berlangsung. Likuifaksi dibagi menjadi dua tipe berdasarkan proses kejadiannya yaitu flow liquefaction dan cyclic mobility. Hal pertama dalam analisis potensi likuifaksi adalah pemeriksaan kerentanan likuifaksi dari karakteristik tanah. Pemeriksaan kerentanan menggunakan empat metode yaitu Chinese criteria, metode Seed et al. dan metode Bray dan Sancio. Jika tanah menunjukan rentan terhadap likuifaksi, perhitungan evaluasi dapat dilanjutkan jika tidak maka perhitungan tidak dilanjutkan. Setelah menentukan kerentanan, tanah yang rentan likuifaksi akan ditentukan tipe likuifaksi menggunakan state criteria. Penentuan tipe likuifaksi dapat dilihat dari grafik hubungan deviatoric stress (q), mean effective stress (p') dan axial strain $\left(\varepsilon_{\mathrm{a}}\right)$. Evaluasi potensi likuifaksi menggunakan metode cyclic strain approach. Metode ini menggunakan dua variabel yaitu cyclic stress ratio (CSR) dan cyclic resistance ratio (CRR) yang dapat ditentukan dari data tes lapangan untuk menentukan potensi likuifaksi setiap lapisan tanah. Tes lapangan yang digunakan adalah standard penetration test (SPT) dan cone penetration test (CPT). Penelitian ini menganalisa potensi cyclic mobility pada tanah kohesif serta faktor keamanan. Hasil dari penelitian ini menunjukan bahwa tipe likuifaksi yang terjadi adalah cyclic mobility dan adanya potensi likuifaksi pada tanah kohesif.
\end{abstract}

Kata kunci: cyclic mobility, flow liquefaction, tanah kohesif, cyclic stress ratio (CSR), cyclic resistance ratio (CRR)

\section{PENDAHULUAN}

Peristiwa gempa merupakan kejadian yang terjadi karena adanya energi dari dalam bumi yang keluar secara tiba-tiba sehingga terjadi getaran di permukaan bumi. Kejadian gempa bumi mengakibatkan kerusakan pada struktur bangunan dan tanah. Resiko kegagalan pada struktur tanah menyebabkan tanah tidak dapat menahan atau menopang struktur bangunan di atas tanah. Hal ini terjadi karena adanya perubahan sifat tanah atau adanya pergerakan tanah saat gempa. Kegagalan tersebut biasanya disebut likuifaksi.

Likuifaksi adalah suatu kejadian dimana tanah mengalami kehilangan daya dukungnya pada jenis tanah yang nonkohesif saat kondisi tanah yang jenuh. Peristiwa likuifaksi merupakan kejadian yang menghasilkan kerusakankerusakan pada bangunan, fondasi, jembatan, dan struktur yang tertanam dalam tanah. Untuk itu, penyelidikan likuifaksi masih dilakukan oleh para peneliti di dunia. Awalnya para peneliti mengemukakan kejadian likuifaksi hanya terjadi pada tanah pasir. Namun ada kejadian likuifaksi yang terjadi di tanah kohesif. Hal itu membuat para peneliti mencoba menyelidiki tanah kohesif dan ternyata ada potensi likuifaksi dengan kondisi tertentu.

Peristiwa likuifaksi yang terjadi di tanah kohesif adalah cyclic mobility. Kegagalan yang diakibatkan oleh cyclic mobility biasanya di struktur yang tertanam dalam tanah seperti fndasi, pipa, dan lain-lain. Fenomena cyclic mobility merupakan kejadian yang kurang diperhatikan karena kurangnya pengetahuan tentang cyclic mobility. Untuk itu perlu adanya penelitian tentang cyclic mobility di tanah kohesif agar menghindari kerusakan yang diakibatkanya.

\section{Rumusan Masalah}

1. Kondisi tanah kohesif yang rentan terhadap likuifaksi.

2. Respon tanah yang rentan terhadap flow liquefaction dan cyclic mobility.

3. Perbandingan hasil potensi likuifaksi pada SPT dan CPT. 


\section{Tujuan Penelitian}

1 Menentukan kondisi tanah kohesif yang rentan terhadap likuifaksi.

2 Menentukan respon tanah yang rentan terhadap flow liquefaction dan cyclic mobility.

3 Menentukan perbandingan potensi likuifaksi pada SPT dan CPT.

\section{Batasan Masalah}

1. Data lapangan yang digunakan adalah SPT dan CPT.

2. Data tanah yang digunakan di daerah Jakarta Selatan.

3. Penentuan kerentanan likuifaksi menggunakan kriteria komposisi.

4. Analisis penentuan flow liquefaction dan cyclic mobility hanya menggunakan consolidated undrained triaxial test.

5. Faktor koreksi pada N lapangan diasumsikan sebesar 1.

6. Penurunan akibat likuifaksi tidak diperhitungkan.

\section{TINJAUAN PUSTAKA}

\section{Studi Pustaka}

Langkah pertama untuk memulai penelitian ini adalah dengan melakukan pencarian referensi berupa studi literatur yang memiliki informasi berupa dasar teori dan menjadi dasar acuan metode analisis yang digunakan untuk menentukan kerentanan, tipe likuifaksi dan evaluasi potensi likuifaksi. Studi literatur yang dilakukan berupa referensi-referensi yang ada seperti jurnal, buku dan internet.

\section{Likuifaksi}

Likuifaksi adalah suatu kejadian pada massa tanah yang kehilangan sebagian besar tahanan geser saat gempa bumi. Kekuatan geser tanah berkurang ditandai dengan nilai tegangan efektif berkurang akibat adanya kenaikan tegangan air pori hingga mencapai overburden pressure pada tanah yang relatif jenuh. Likuifaksi dibagi menjadi dua tipe yaitu cyclic mobility dan flow liquefaction. Perbedaan dari kedua tipe tersebut adalah dampaknya. Setelah kejadian flow liquefaction, tanah yang awalnya padat akan menjadi cair sedangkan cyclic mobility tidak menjadi cair. Tanah akan menjadi cair karena tegangan efektif mencapai nol sehingga tanah akan menjadi lunak. Perbedaan flow liquefaction dan cyclic mobility dapat dilihat pada Tabel 1.

Tabel 1 Perbedaan Flow Liquefaction dan Cyclic Mobility (Schneider dan Mayne, 1999)

\begin{tabular}{ccc}
\hline & \multicolumn{2}{c}{ Tipe Likuifaksi } \\
\cline { 2 - 3 } Reaksi regangan tanah & Strain softening & Cyclic Mobility \\
\hline Kondisi tegangan & Tegangan efektif mencapai nol & Tegangan efektif tidak mencapai nol \\
\hline Karakteristik tanah & $\begin{array}{c}\text { Tanah jenuh dengan kepadatan } \\
\text { yang longgar }\end{array}$ & $\begin{array}{c}\text { Tanah jenuh dengan kepadatan yang } \\
\text { longgar atau padat }\end{array}$ \\
\hline Potensi kegagalan & $\begin{array}{c}\text { Tanah akan menjadi lunak dan } \\
\text { mengalir seperti cairan } \\
\text { tergantung pada kemiringan di } \\
\text { suatu daerah }\end{array}$ & $\begin{array}{c}\text { Deformasi tanah akan melebar atau } \\
\text { meluas selama gempa bumi } \\
\text { berlangsung }\end{array}$ \\
\hline
\end{tabular}

\section{Kerentanan Likuifaksi}

Untuk mengetahui potensi likuifaksi pada tanah, perlu adanya evaluasi agar dapat menentukan potensi likuifaksi tiap kedalaman. Hal pertama yang harus dievaluasi adalah kerentanan tanah terhadap likuifaksi. Jika tanah bersifat rentan (susceptible), analisis potensi likuifaksi harus di perhitungkan. Jika tanah tidak bersifat rentan, analisis potensi likuifaksi tidak diperlukan. Kriteria yang digunakan dalam mengevaluasi kerentanan likuifaksi adalah kriteria sejarah, geologi, dan komposisi. Penelitian ini hanya menggunakan kriteria komposisi untuk menentukan kerentanan likuifaksi. 


\section{State Criteria}

State criteria digunakan untuk menentukan tipe likuifaksi yaitu flow liquefaction dan cyclic mobility. Terdapat 3 bentuk grafik untuk membedakan tipe likuifaksi. Grafik tersebut dapat dilihat pada Gambar 1.

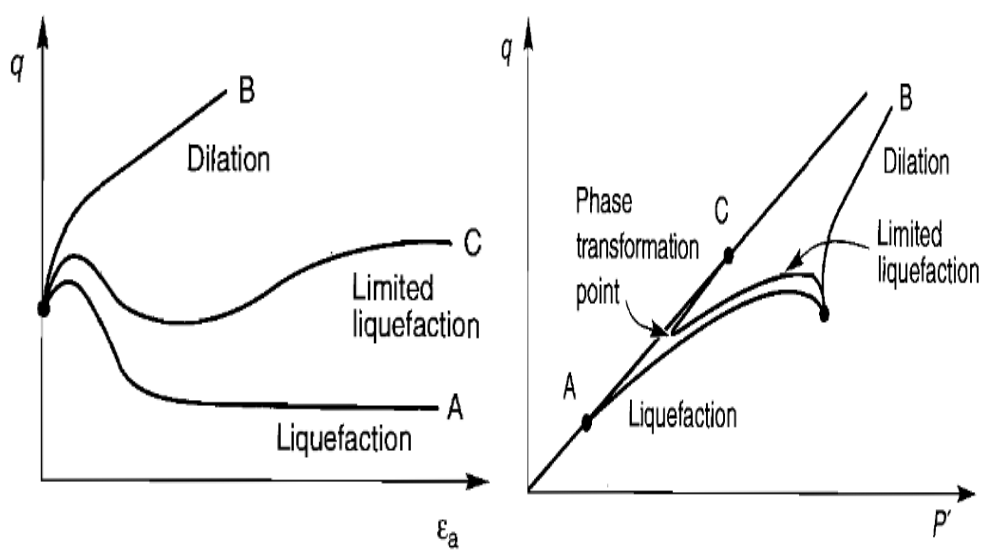

Gambar 1 Grafik Liquefaction, Limited Liquefaction dan Dilation (Kramer, 1996)

Pada grafik deviatoric stress $(q)$ dengan axial stress $\left(\varepsilon_{\mathrm{a}}\right)$, istilah liquefaction adalah strain softening, limited liquefaction adalah limited strain softening dan dilation adalah strain hardening. Strain softening adalah suatu kondisi dimana tanah semakin lunak sedangkan strain hardening adalah kondisi tanah yang semakin padat. Limited strain softening adalah batas antara strain softening dan strain hardening.

Pada grafik deviatoric stress (q) dengan mean effective stress (p'), terdapat 2 garis untuk menentukan tipe likuifaksi yaitu steady state line (SSL) dan flow liquefaction surface (FLS). SSL merupakan garis konstan yang dibentuk dari deviatoric stress dan mean effective stress. FLS adalah garis puncak untuk menentukan flow liquefaction. Dari kedua grafik tersebut dapat terbentuknya zona flow liquefaction dan cyclic mobility seperti pada Gambar 2.

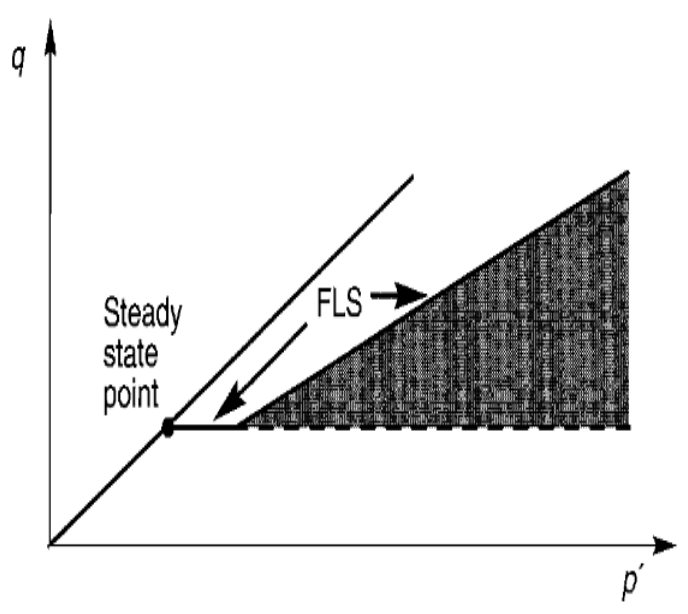

(a)

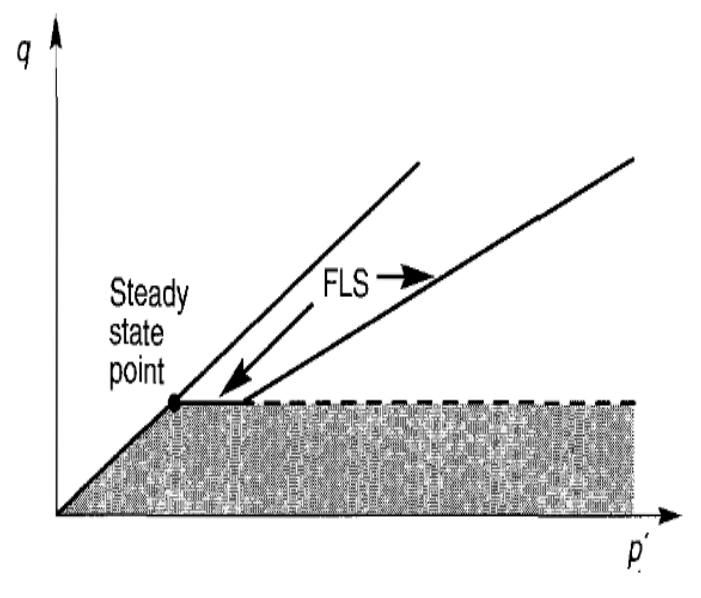

(b)

Gambar 2 Daerah (a) Flow Liquefaction dan (b) Cyclic Mobility (Kramer, 1996)

\section{Evaluasi Potensi Likuifaksi}

Setelah mengetahui kerentanan tanah maka langkah selanjutnya adalah mengevaluasi potensi likuifaksi pada lapisan tanah. Evaluasi ini bertujuan untuk menentukan potensi likuifaksi setiap lapisan tanah. Metode yang digunakan adalah cyclic stress approach (Seed and Idriss, 1971). Metode ini menggunakan dua variabel yaitu cyclic stress ratio (CSR) dan cyclic resistance ratio (CRR) yang dapat ditentukan dari data standard penetration test (SPT) dan cone penetration test (CPT). 


\section{Cyclic Stress Ratio (CSR)}

CSR adalah nilai tegangan yang disebabkan oleh gempa bumi. Untuk evaluasi CSR diusulkan oleh Seed dan Idriss (1971) menggunakan persamaan berikut:

$$
C S R=0.65 \times \frac{a_{\max }}{g} \times \frac{\sigma}{\sigma^{\prime}} \times r_{d}
$$

Dengan $\sigma^{\prime}$ adalah tegangan efektif tanah, $\sigma$ adalah tegangan total tanah, $\mathrm{a}_{\max }$ adalah percepatan gempa maksimum pada permukaan, g adalah gravitasi dan $r_{d}$ adalah faktor reduksi.

\section{Cyclic Resistance Ratio (CRR)}

Dalam analisa potensi likuifaksi dibutuhkan suatu variabel yang bisa diinterpetasikan dalam sebuah persamaan yang dapat mendefinisikan tahanan tanah terhadap likuifaksi dengan simbol CRR. Perhitungan CRR berbeda tiap tes.

Perhitungan CRR untuk tes SPT:

$$
C R R=\frac{1}{34-\left(N_{1}\right)_{60}}+\frac{\left(N_{1}\right)_{60}}{135}+\frac{50}{\left(10 .\left(N_{1}\right)_{60}+45\right)^{2}}-\frac{1}{200}
$$

Dengan $\left(N_{1}\right)_{60}$ adalah SPT lapangan yang telah terkoreksi oleh beberapa faktor.

Perhitungan CRR untuk tes CPT:

$$
C R R=\left\{\begin{array}{cc}
0.833 \times \frac{\left(q_{c 1 N}\right)}{1000}+0.05 & \text { untuk } q_{c 1 N}<50 \\
93 \times\left(\frac{\left(q_{c 1 N}\right)}{1000}\right)^{3}+0.08 & \text { untuk } 50<q_{c 1 N}<160
\end{array}\right.
$$

Dengan $q_{c 1 N}$ adalah tahanan ujung konus yang terkoreksi

Setelah mendapakan nilai CSR dan CRR, langkah selanjutnya adalah penentuan nilai factor of safety (FS). Perhitungan nilai FS adalah perbandingan nilai CRR dengan CSR.

$$
F S=\frac{C R R}{C S R}
$$

Jika nilai FS $\leq 1$, maka tanah akan mengalami likuifaksi, sedangkan bila nilai FS $>1$, maka tidak akan terjadi likuifaksi.

\section{METODE PENELITIAN}

\section{Pengumpulan Data Tanah}

Pada penelitian ini, data yang digunakan adalah data tes laboratorium dan lapangan yaitu CPT dan SPT di daerah Jakarta Selatan. Data laboratorium digunakan untuk menentukan kerentanan likuifaksi dan tipe likuifaksi sedangkan data dari CPT dan SPT akan digunakan untuk menentukan potensi likuifaksi dari hasil analisis CSR dan CRR. Pengujian tes laboratorium yang digunakan adalah grain size analysis, atterberg limits dan consolidated undrained triaxial test sedangkan untuk tes lapangan menggunakan SPT dan CPT.

\section{Analisis Potensi Likuifaksi}

Hal pertama dalam analisis ini adalah menentukan kerentanan likuifaksi menggunakan data dari tes laboratorium. Data dari laboratorium yang digunakan adalah indeks plastisitas (PI), batas cair (LL), water content $\left(\mathrm{W}_{\mathrm{c}}\right)$, dan diameter butiran. Data tersebut akan dimasukan ke dalam kriteria komposisi.

Setelah penentuan kerentanan likuifaksi, tipe likuifaksi dapat ditentukan dengan menggunakan data consolidated undrained triaxial test untuk membentuk batas flow liquefaction dan cyclic mobility.

Yang terakhir adalah analisa potensi likuifaksi menggunakan data dari SPT dan CPT pada tanah yang rentan likuifaksi. Data tersebut akan digunakan untuk menentukan CSR dan CRR. Setelah mendapakan nilai CSR dan CRR, langkah selanjutnya adalah penentuan nilai FS dengan membandingkan CSR dan CRR. 


\section{ANALISIS DAN PEMBAHASAN}

Langkah pertama untuk menentukan potensi likuifaksi adalah menentukan kerentanan likuifaksi. Dari data laboratorium, ada 9 titik bor dengan total pengambilan sampel sebanyak 31 sampel. Masing-masing sampel dianalisa untuk menentukan kerentanan likuifaksi.

\section{Kriteria Komposisi}

Penentuan kerentanan likuifaksi dalam kriteria komposisi menggunakan nilai indeks plastisitas (PI), batas cair (LL), dan water content $\left(\mathrm{W}_{\mathrm{C}}\right)$. Dalam kriteria ini, metode yang digunakan adalah Chinese criteria (Wang, 1979), Seed et al. (2003), dan Bray and Sancio (2006). Berikut hasil penentuan kerentanan likuifaksi.

Tabel 2 Hasil Penentuan Kerentanan Likuifaksi

\begin{tabular}{|c|c|c|c|c|c|c|c|c|}
\hline \multirow{2}{*}{\multicolumn{2}{|c|}{ Boring No. }} & \multirow{2}{*}{$\begin{array}{c}\text { PI } \\
\text { (\%) }\end{array}$} & \multirow{2}{*}{$\begin{array}{l}\text { LL } \\
\text { (\%) }\end{array}$} & \multirow{2}{*}{$\begin{array}{c}\mathrm{W}_{\mathrm{c}} \\
(\%)\end{array}$} & \multirow{2}{*}{$\mathrm{W}_{\mathrm{c}} / \mathrm{LL}$} & \multicolumn{3}{|c|}{ Liquefaction Susceptible } \\
\hline & & & & & & Chinese Criteria & Seed et al. & Bray and Sancio \\
\hline \multirow{3}{*}{ DB1 } & UD1 & 74.21 & 98.59 & 60.61 & 0.61 & NO & NO & NO \\
\hline & UD2 & 56.16 & 96.24 & 76.11 & 0.79 & NO & NO & NO \\
\hline & UD3 & 40.86 & 81.50 & 81.50 & 1.00 & NO & NO & NO \\
\hline \multirow{3}{*}{ DB2 } & UD1 & 42.73 & 91.30 & 50.09 & 0.55 & NO & NO & NO \\
\hline & UD2 & 36.38 & 81.60 & 57.93 & 0.71 & NO & NO & NO \\
\hline & UD3 & 41.56 & 79.18 & 78.19 & 0.99 & NO & NO & NO \\
\hline \multirow{5}{*}{ DB3 } & UD1 & 50.48 & 94.00 & 47.35 & 0.50 & NO & NO & NO \\
\hline & UD2 & 37.50 & 85.20 & 52.50 & 0.62 & NO & NO & NO \\
\hline & UD3 & 22.88 & 75.20 & 73.08 & 0.97 & NO & NO & NO \\
\hline & UD4 & 11.59 & 50.95 & 61.59 & 1.21 & NO & NO & YES \\
\hline & MZ2 & 38.41 & 80.20 & 46.88 & 0.58 & NO & NO & NO \\
\hline \multirow{3}{*}{ DB4 } & UD1 & 47.15 & 86.90 & 55.07 & 0.63 & NO & NO & NO \\
\hline & UD2 & 28.17 & 77.50 & 83.54 & 1.08 & NO & NO & NO \\
\hline & UD3 & 21.67 & 56.30 & 72.92 & 1.30 & NO & NO & NO \\
\hline \multirow{7}{*}{ DB5 } & UD1 & 53.27 & 98.40 & 49.43 & 0.50 & NO & NO & NO \\
\hline & UD2 & 44.80 & 85.15 & 50.19 & 0.59 & NO & NO & NO \\
\hline & UD3 & 9.24 & 53.25 & 60.05 & 1.13 & NO & NO & YES \\
\hline & UD4 & 24.72 & 68.55 & 53.22 & 0.78 & NO & NO & NO \\
\hline & UD5 & 32.37 & 74.40 & 75.25 & 1.01 & NO & NO & NO \\
\hline & UD6 & 31.57 & 70.85 & 44.79 & 0.63 & NO & NO & NO \\
\hline & UD7 & 47.64 & 87.75 & 48.13 & 0.55 & NO & NO & NO \\
\hline \multirow{3}{*}{ DB6 } & UD1 & 26.94 & 60.90 & 42.81 & 0.70 & NO & NO & NO \\
\hline & UD2 & 23.47 & 65.40 & 72.81 & 1.11 & NO & NO & NO \\
\hline & UD3 & 21.12 & 64.10 & 94.82 & 1.48 & NO & NO & NO \\
\hline \multirow{4}{*}{ DB7 } & UD1 & 36.14 & 73.60 & 50.52 & 0.69 & NO & NO & NO \\
\hline & UD2 & 57.42 & 94.45 & 67.12 & 0.71 & NO & NO & NO \\
\hline & UD3 & 10.81 & 48.85 & 49.93 & 1.02 & NO & NO & YES \\
\hline & MZ2 & 47.70 & 86.45 & 50.32 & 0.58 & NO & NO & NO \\
\hline \multirow{3}{*}{ DB8 } & UD1 & 38.51 & 74.40 & 75.25 & 1.01 & NO & NO & NO \\
\hline & UD2 & 72.30 & 70.85 & 44.79 & 0.63 & NO & NO & NO \\
\hline & UD3 & 31.31 & 87.75 & 48.13 & 0.55 & NO & NO & NO \\
\hline
\end{tabular}

Dari tabel di atas, titik yang rentan terhadap likuifaksi adalah titik DB3, DB5 dan DB7.

\section{State Criteria}

Pada kriteria ini, data yang diperlukan adalah data consolidated undrained triaxial test. Titik yang ditinjau adalah DB3, DB5 dan DB7 karena menunjukan kerentanan likuifaksi berdasarkan kriteria komposisi. Dari tabel-tabel di atas, dapat dibentuk grafik q-p’ dan q- $\varepsilon_{\mathrm{a}}$. Berikut grafik pada masing-masing titik DB3, DB5 dan DB7. 

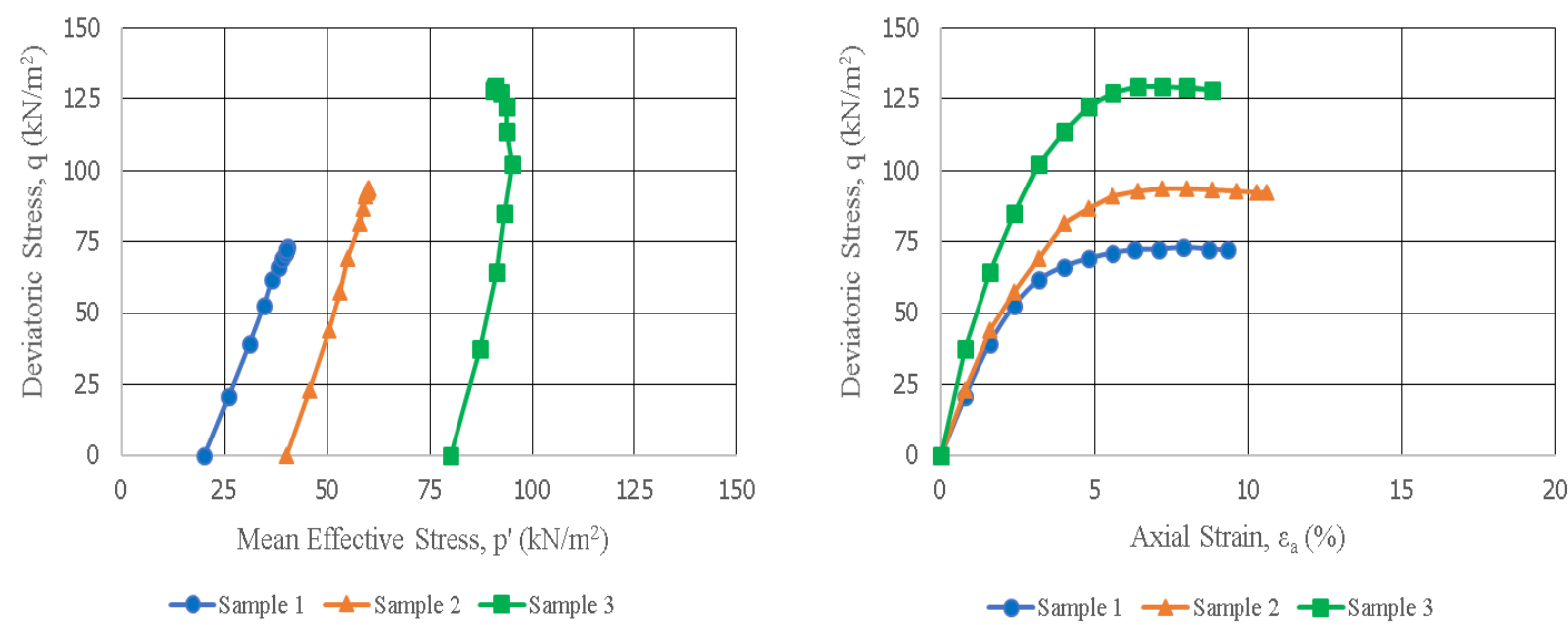

Gambar 3 Grafik Hubungan q-p’ dan q- $\varepsilon_{\mathrm{a}}$ pada DB3
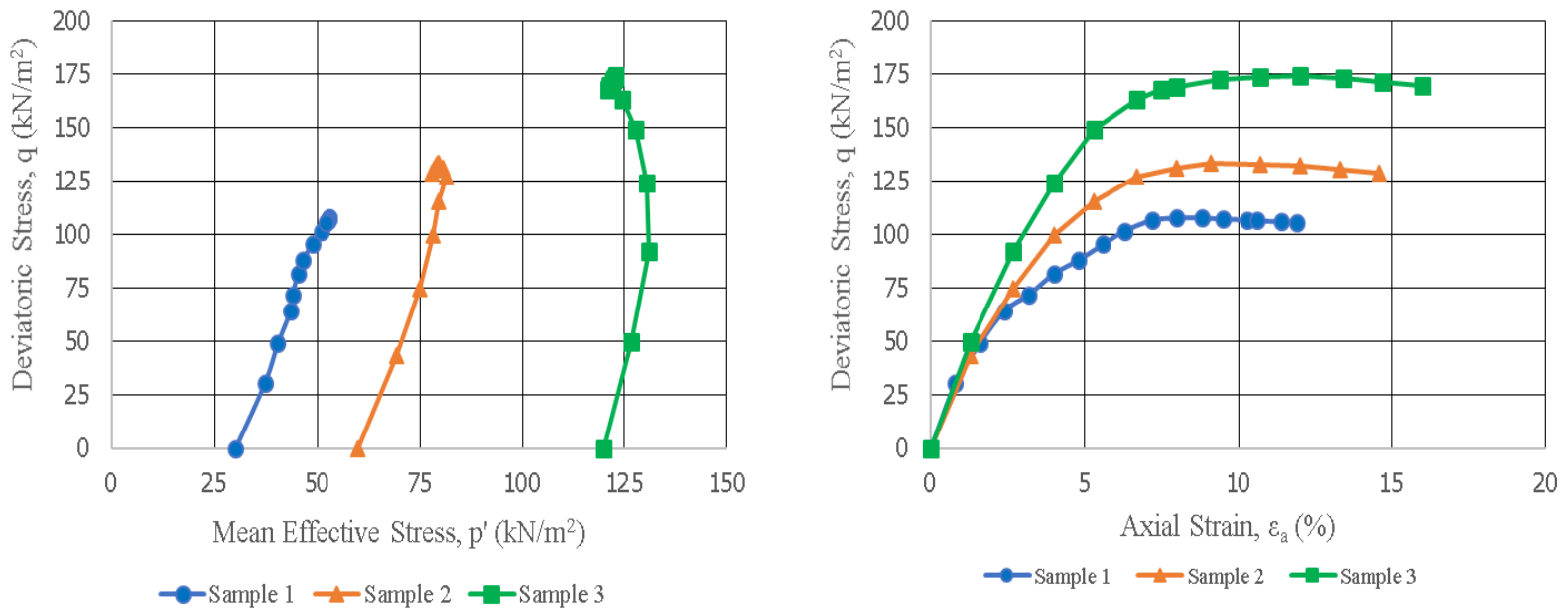

Gambar 4 Grafik Hubungan q-p’ dan q- $\varepsilon_{a}$ pada DB5
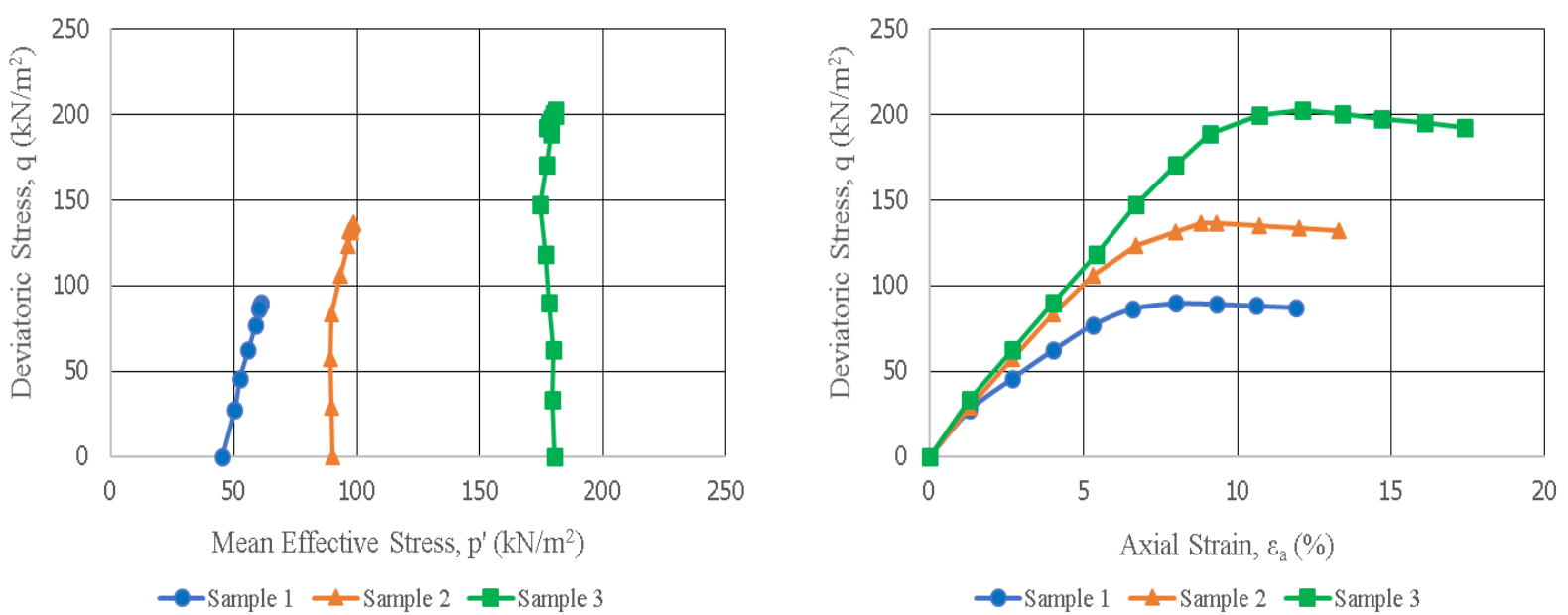

Gambar 5 Grafik Hubungan q-p’ dan q- $\varepsilon_{\text {a }}$ pada DB7 
Dari hasil di atas dapat, tipe likuifaksi yang terjadi adalah cyclic mobility karena garis FLS tidak terbentuk dan pada grafik strain menunjukan strain hardening.

\section{Evaluasi Potensi Likuifaksi}

Setelah menentukan kerentanan likuifaksi, perhitungan potensi likuifaksi dapat dilanjutkan. Data yang dibutuhkan untuk menentukan CSR dan CRR adalah data SPT dan CPT yang rentan terhadap likuifaksi. Nilai CSR dan CRR akan dibandingkan untuk mendapatkan nilai FS. Nilai FS tersebut akan mengindentifikasi adanya potensi likufaksi atau tidak pada kedalaman tertentu.

Tabel 3 Hasil Perhitungan Potensi Likuifaksi Data SPT pada DB3

\begin{tabular}{ccccccc}
\hline Depth $(\mathrm{m})$ & $\mathrm{N}$ & Jenuh & CSR & CRR & FS & Likuifaksi \\
\hline 1 & 3 & Tidak Jenuh & 0.239 & 0.08 & 0.333 & N/A \\
2 & 4 & Tidak Jenuh & 0.237 & 0.088 & 0.369 & N/A \\
4 & 3 & Tidak Jenuh & 0.234 & 0.065 & 0.277 & N/A \\
6 & 6 & Tidak Jenuh & 0.23 & 0.08 & 0.346 & N/A \\
8 & 5 & Tidak Jenuh & 0.225 & 0.072 & 0.32 & N/A \\
10 & 4 & Tidak Jenuh & 0.218 & 0.065 & 0.298 & N/A \\
12 & 4 & Jenuh & 0.221 & 0.058 & 0.264 & YES \\
14 & 5 & Jenuh & 0.222 & 0.065 & 0.292 & YES \\
16 & 4 & Jenuh & 0.216 & 0.058 & 0.27 & YES \\
18 & 4 & Jenuh & 0.211 & 0.058 & 0.277 & YES \\
20 & 8 & Jenuh & 0.202 & 0.072 & 0.357 & YES \\
22 & 50 & Jenuh & 0.177 & 0.292 & 1.653 & NO \\
24 & 50 & Jenuh & 0.172 & 0.273 & 1.594 & NO \\
26 & 50 & Jenuh & 0.168 & 0.257 & 1.531 & NO \\
28 & 50 & Jenuh & 0.165 & 0.257 & 1.556 & NO \\
30 & 47 & Jenuh & 0.181 & 0.292 & 1.613 & NO \\
\hline
\end{tabular}

Tabel 4 Hasil Perhitungan Potensi Likuifaksi Data CPT pada DB3

\begin{tabular}{ccccccc}
\hline Depth $(\mathrm{m})$ & qc $\left(\mathrm{kg} / \mathrm{cm}^{2}\right)$ & Jenuh & CSR & CRR & FS & Likuifaksi \\
\hline 2 & 15.241 & Tidak Jenuh & 0.237 & 0.071 & 0.301 & N/A \\
4 & 25.547 & Tidak Jenuh & 0.234 & 0.075 & 0.322 & N/A \\
6 & 22.299 & Tidak Jenuh & 0.23 & 0.068 & 0.295 & N/A \\
8 & 22.723 & Tidak Jenuh & 0.225 & 0.066 & 0.292 & N/A \\
10 & 22.585 & Tidak Jenuh & 0.218 & 0.064 & 0.295 & N/A \\
12 & 37.127 & Jenuh & 0.226 & 0.072 & 0.317 & YES \\
14 & 32.467 & Jenuh & 0.227 & 0.069 & 0.303 & YES \\
16 & 45.031 & Jenuh & 0.218 & 0.074 & 0.341 & YES \\
17.7 & 24.576 & Jenuh & 0.214 & 0.063 & 0.295 & YES \\
18 & 80.474 & Jenuh & 0.208 & 0.091 & 0.438 & YES \\
18.3 & 188.018 & Jenuh & 0.208 & 0.228 & 1.094 & NO \\
19 & 54.422 & Jenuh & 0.205 & 0.078 & 0.379 & YES \\
19.5 & 156.591 & Jenuh & 0.202 & 0.156 & 0.775 & YES \\
20 & 106.024 & Jenuh & 0.2 & 0.103 & 0.516 & YES \\
21.5 & 63.839 & Jenuh & 0.197 & 0.081 & 0.413 & YES \\
22 & 94.024 & Jenuh & 0.194 & 0.095 & 0.488 & YES \\
23 & 65.422 & Jenuh & 0.194 & 0.081 & 0.42 & YES \\
23.8 & 259.924 & Jenuh & 0.188 & 0.35 & 1.864 & NO \\
\hline
\end{tabular}


Tabel 5 Hasil Perhitungan Potensi Likuifaksi Data SPT pada DB5

\begin{tabular}{ccccccc}
\hline Depth $(\mathrm{m})$ & $\mathrm{N}$ & Jenuh & CSR & CRR & FS & Likuifaksi \\
\hline 1 & 3 & Tidak Jenuh & 0.239 & 0.080 & 0.333 & N/A \\
2 & 4 & Tidak Jenuh & 0.237 & 0.088 & 0.369 & N/A \\
4 & 3 & Tidak Jenuh & 0.234 & 0.065 & 0.277 & N/A \\
6 & 5 & Tidak Jenuh & 0.230 & 0.072 & 0.313 & N/A \\
8 & 6 & Tidak Jenuh & 0.225 & 0.080 & 0.354 & N/A \\
10 & 5 & Tidak Jenuh & 0.218 & 0.065 & 0.298 & N/A \\
12 & 4 & Tidak Jenuh & 0.206 & 0.058 & 0.283 & N/A \\
14 & 3 & Jenuh & 0.207 & 0.053 & 0.255 & YES \\
16 & 14 & Jenuh & 0.203 & 0.104 & 0.514 & YES \\
18 & 8 & Jenuh & 0.197 & 0.072 & 0.366 & YES \\
20 & 18 & Jenuh & 0.191 & 0.122 & 0.639 & YES \\
22 & 17 & Jenuh & 0.185 & 0.113 & 0.611 & YES \\
24 & 45 & Jenuh & 0.166 & 0.228 & 1.374 & NO \\
26 & 50 & Jenuh & 0.163 & 0.257 & 1.577 & NO \\
28 & 50 & Jenuh & 0.161 & 0.242 & 1.508 & NO \\
30 & 50 & Jenuh & 0.178 & 0.338 & 1.896 & NO \\
\hline
\end{tabular}

Tabel 6 Hasil Perhitungan Potensi Likuifaksi Data CPT pada DB5

\begin{tabular}{ccccccc}
\hline Depth $(\mathrm{m})$ & qc $\left(\mathrm{kg} / \mathrm{cm}^{2}\right)$ & Jenuh & CSR & CRR & FS & Likuifaksi \\
\hline 2 & 23.220 & Tidak Jenuh & 0.237 & 0.083 & 0.348 & N/A \\
4 & 32.658 & Tidak Jenuh & 0.234 & 0.082 & 0.352 & N/A \\
6 & 22.470 & Tidak Jenuh & 0.230 & 0.068 & 0.296 & N/A \\
8 & 25.136 & Tidak Jenuh & 0.225 & 0.068 & 0.300 & N/A \\
10 & 24.529 & Tidak Jenuh & 0.218 & 0.065 & 0.300 & N/A \\
12 & 28.829 & Jenuh & 0.227 & 0.067 & 0.297 & YES \\
14 & 39.201 & Jenuh & 0.225 & 0.072 & 0.320 & YES \\
15 & 45.671 & Jenuh & 0.222 & 0.075 & 0.338 & YES \\
16 & 38.828 & Jenuh & 0.218 & 0.071 & 0.325 & YES \\
16.7 & 64.475 & Jenuh & 0.215 & 0.084 & 0.392 & YES \\
17.7 & 41.744 & Jenuh & 0.211 & 0.072 & 0.341 & YES \\
18 & 61.585 & Jenuh & 0.209 & 0.082 & 0.392 & YES \\
18.5 & 28.369 & Jenuh & 0.211 & 0.065 & 0.309 & YES \\
19 & 54.743 & Jenuh & 0.205 & 0.078 & 0.380 & YES \\
20 & 46.263 & Jenuh & 0.202 & 0.073 & 0.363 & YES \\
21 & 33.108 & Jenuh & 0.203 & 0.067 & 0.330 & YES \\
21.2 & 80.520 & Jenuh & 0.196 & 0.089 & 0.454 & YES \\
22 & 37.011 & Jenuh & 0.196 & 0.068 & 0.347 & YES \\
22.5 & 74.583 & Jenuh & 0.193 & 0.085 & 0.443 & YES \\
23.72 & 259.313 & Jenuh & 0.188 & 0.350 & 1.857 & NO \\
\hline
\end{tabular}


Tabel 7 Hasil Perhitungan Potensi Likuifaksi Data SPT pada DB7

\begin{tabular}{ccccccc}
\hline Depth $(\mathrm{m})$ & $\mathrm{N}$ & Jenuh & CSR & CRR & FS & Likuifaksi \\
\hline 2 & 2 & Tidak Jenuh & 0.234 & 0.065 & 0.277 & N/A \\
4 & 2 & Tidak Jenuh & 0.230 & 0.058 & 0.253 & N/A \\
6 & 1 & Jenuh & 0.206 & 0.049 & 0.239 & YES \\
8 & 4 & Jenuh & 0.234 & 0.065 & 0.277 & YES \\
10 & 7 & Jenuh & 0.246 & 0.080 & 0.324 & YES \\
12 & 27 & Jenuh & 0.247 & 0.228 & 0.926 & YES \\
14 & 50 & Jenuh & 0.219 & 0.558 & 2.553 & NO \\
16 & 50 & Jenuh & 0.207 & 0.410 & 1.982 & NO \\
18 & 50 & Jenuh & 0.197 & 0.370 & 1.879 & NO \\
20 & 50 & Jenuh & 0.215 & 1.240 & 5.759 & NO \\
22 & 50 & Jenuh & 0.183 & 0.313 & 1.713 & NO \\
24 & 50 & Jenuh & 0.178 & 0.292 & 1.636 & NO \\
26 & 50 & Jenuh & 0.205 & 0.468 & 2.285 & NO \\
28 & 50 & Jenuh & 0.203 & 0.410 & 2.023 & NO \\
30 & 50 & Jenuh & 0.170 & 0.257 & 1.511 & NO \\
\hline
\end{tabular}

Tabel 8 Hasil Perhitungan Potensi Likuifaksi Data CPT pada DB7

\begin{tabular}{ccccccc}
\hline Depth $(\mathrm{m})$ & qc $\mathrm{kg} / \mathrm{cm}^{2}$ & Jenuh & CSR & CRR & FS & Likuifaksi \\
\hline 1 & 23.589 & Tidak Jenuh & 0.239 & 0.083 & 0.349 & N/A \\
2 & 24.246 & Tidak Jenuh & 0.237 & 0.084 & 0.354 & N/A \\
4 & 19.928 & Tidak Jenuh & 0.234 & 0.070 & 0.298 & N/A \\
5.7 & 17.286 & Tidak Jenuh & 0.231 & 0.064 & 0.279 & N/A \\
6 & 25.747 & Tidak Jenuh & 0.230 & 0.071 & 0.308 & N/A \\
8 & 41.953 & Tidak Jenuh & 0.225 & 0.078 & 0.347 & N/A \\
9 & 30.804 & Tidak Jenuh & 0.222 & 0.070 & 0.313 & N/A \\
9.5 & 40.973 & Tidak Jenuh & 0.220 & 0.075 & 0.342 & N/A \\
10 & 31.453 & Tidak Jenuh & 0.218 & 0.070 & 0.320 & N/A \\
10.5 & 32.073 & Jenuh & 0.221 & 0.070 & 0.316 & YES \\
11.7 & 257.639 & Jenuh & 0.224 & 0.592 & 2.640 & NO \\
\hline
\end{tabular}

\section{KESIMPULAN}

- Berdasarkan hasil yang didapatkan, hasil pemeriksaan kerentanan likuifaksi sesuai kriteria komposisi pada metode Bray dan Sancio menunjukan adanya kerentanan likuifaksi pada DB3, DB5 dan DB7.

- Dari hasil penentuan tipe likuifaksi, respon tanah pada grafik hubungan q-p' tidak terbentuk garis FLS dan grafik hubungan $\mathrm{q}-\varepsilon_{\mathrm{a}}$ menunjukan strain hardening sehingga tipe likuifaksi yang terjadi adalah cyclic mobility.

- $\quad$ Pada perhitungan potensi likuifaksi, SPT dan CPT menunjukan hasil potensi likuifaksi yang hampir sama.

\section{DAFTAR PUSTAKA}

Bray, J.D., and Sancio, R.B. 2006. Assessment of the Liquefaction Susceptibility Offine-Grained Soils. Journal of Geotechnical and Geoenvironmental Engineering. 132(9): 1165-1177.

Kramer, Steven L. 1996. Geotechnical Earthquake Engineering. Upper Seadle River: Pearson.

Schneider, James A. and Paul W. Mayne. 1999. Soil Liquefaction Response in Mid-America Evaluated by Seismic Piezocone Tests. Atlanta: Georgia Institute of Technology.

Seed, H.B., and I.M. Idriss. 1971. Simplified Procedure for Evaluating Soil Liquefaction Potential. Journal of Soil Mechanics and Foundation Division. 97(9): 1249-1273.

Seed et al. 2003. Recent Advances in Soil Liquefaction Engineering: a Unified and Consistent Framework. California: 26th Annual ASCE Los Angeles Geotechnical Spring Seminar.

Wang, W.S. 1979. Some findings in soil liquefaction. Beijing: Water Conservancy and Hydroelectric Power Scientific Research Institute. 
